\title{
Non-isotopic analysis of single strand conformation polymorphism (SSCP) in the exon 13 region of the human dystrophin gene
}

\author{
U Lenk, R Hanke, U Kräft, K Grade, I Grunewald, A Speer
}

\begin{abstract}
More than $30 \%$ of Duchenne and Becker muscular dystrophy (DMD/BMD) patients have no gross DNA rearrangements like deletions or duplications. The large size of the coding sequence of the dystrophin gene (11 kilobases) complicates systematic identification of point mutations. Recently reported approaches based on genomic DNA or mRNA show that chemical cleavage of mismatches is an effective but time consuming and technically demanding method for the identification of point mutations in the human dystrophin gene. We have used a fast and convenient system consisting of PCR amplification of genomic DNA, non-isotopic SSCP analysis, and direct sequencing of PCR products for the detection of mutations in exon 13 and adjacent intron sequences. Sixty-eight DMD patients without detectable deletions or duplications were analysed, resulting in the identification of a point mutation in the coding sequence and two polymorphisms in the $5^{\prime}$ flanking intron. The $C$ to $T$ change of the first nucleotide in the third triplet leads to a stop codon and seems to be the cause of the functional deficiency of the gene product in this patient.

( $\mathcal{F}$ Med Genet 1993;30:951-4)
\end{abstract}

Around 60 to $70 \%$ of patients suffering from Duchenne or Becker muscular dystrophy (DMD or BMD) have deletions or duplications of parts of the dystrophin gene. ${ }^{1-3}$ The remaining one-third of $\mathrm{DMD} / \mathrm{BMD}$ cases do not have gross rearrangements of the dystrophin gene. Therefore small structural alterations like point mutations are presumed to be responsible for the defective dystrophin.

Owing to the large size of the coding sequence of the dystrophin gene (11 kilobases, ${ }^{4}$ 79 exons $^{5}$ ) the systematic identification of point mutations is difficult. Up to now about 10 point mutations have been detected by immunological analysis, ${ }^{6}$ or by chemical cleavage of amplified products of reverse transcribed dystrophin mRNA ${ }^{7}$ or PCR amplified genomic $\mathrm{DNA}^{8}$ in combination with sequencing. However, although effective, the chemical cleavage $^{910}$ method is technically demanding especially for routine diagnoses. In addition, this approach involves the use of hazardous chemicals and radioactive labelling.

Therefore we turned to another promising method for the detection of sequence variants in PCR amplified DNA fragments: the single strand conformation polymorphism technique (PCR-SSCP). It is based on the fact that the electrophoretic mobility of single stranded DNA in non-denaturing polyacrylamide gels depends not only on its size but also on its sequence. ${ }^{11-13}$ The feasibility of the PCRSSCP technique for detecting DNA alterations has already been shown for other genetic diseases. ${ }^{14-16}$ However, in contrast to most of the published examples, we performed a nonisotopic procedure for the identification of unknown mutations using an extremely sensitive silver staining to visualise double and single stranded DNA. ${ }^{17-19}$

In this study we have applied non-isotopic PCR-SSCP analysis coupled with silver staining of non-denaturing polyacrylamide gels to detect sequence heterogeneities in the exon 13 region of the human dystrophin gene. Analysis of the DNA from $68 \mathrm{DMD} / \mathrm{BMD}$ patients has identified a mutation generating a termination codon and two polymorphisms in the $5^{\prime}$ upstream intron adjacent to exon 13.

\section{Materials and methods}

PATIENTS AND DNA ISOLATION

Preparation of DNA from lymphocytes of patients was performed as described previously..$^{20}$ No abnormalities had been found by genomic PCR of selected exons and Southern blot analysis.

\section{DNA AMPLIFICATION}

PCR amplification ${ }^{21}$ of genomic sequences encompassing exon 13 (length $238 \mathrm{bp}$ ) was performed using up to $500 \mathrm{ng}$ of genomic DNA, $10 \mathrm{pmol}$ each of primers $13 \mathrm{~F}$ and $13 \mathrm{R},{ }^{22}$ $200 \mu \mathrm{mol} / 1 \mathrm{dNTPs}, 5 \mu \mathrm{l}$ of $10 \times$ Taq DNA polymerase buffer, and 2.5 U Taq DNA polymerase (Amersham) in a total volume of $50 \mu \mathrm{l}$. The reaction mixtures were overlayed with $50 \mu \mathrm{l}$ paraffin oil (Merck) and 25 cycles of PCR $\left(95^{\circ} \mathrm{C}\right.$ for one minute, $58^{\circ} \mathrm{C}$ for one to two minutes, $72^{\circ} \mathrm{C}$ for one minute) were carried out, followed by a final extension $\left(72^{\circ} \mathrm{C}\right.$ for 10 minutes) in a Techne PHC-1 thermocycler.

\section{SSCP ANALYSIS}

PCR reaction products $(0.5$ to $1 \mu \mathrm{l})$ were mixed with $1 \mu \mathrm{l}$ of $0.2 \mathrm{~mol} / 1 \mathrm{NaCl}$ and $3 \mu \mathrm{l}$ of deionised formamide $/ 0 \cdot 2 \mathrm{~mol} / 1$ EDTA solution. Samples were denatured at $95^{\circ} \mathrm{C}$ for five minutes, quick chilled on ice, and then loaded 
onto a 5\% non-denaturing horizontal polyacrylamide gel containing $90 \mathrm{mmol} / 1$ Trisborate, $2 \mathrm{mmol} / 1 \mathrm{EDTA}, \mathrm{pH} 8.3$, and $10 \%$ glycerol. The gel was bound to FMC Gelbond PAG (Biozym). Electrophoresis was performed at $500 \mathrm{~V}$ for five to seven hours at $20^{\circ} \mathrm{C}$ on an adapted TGGE device (Diagen). After electrophoresis the gels were silver stained (Diagen) as follows. The gel was incubated twice with $300 \mathrm{ml}$ of a $10 \%$ ethanol $/ 0 \cdot 5 \%$ acetic acid solution for three minutes. After washing with deionised water it was incubated for 10 to 15 minutes with $300 \mathrm{ml}$ of a $0 \cdot 1 \%$ $\mathrm{AgNO}_{3}$ solution. Then the gel was washed twice again followed by incubation (up to 10 minutes) with a freshly prepared mixture of $1.5 \% \mathrm{NaOH}, 0.01 \% \mathrm{NaBH}_{2}$, and $0.15 \%$ formaldehyde. The gel was washed again and then soaked for up to five minutes with a $0.75 \% \mathrm{NaCO}_{3}$ solution. Gels can be sealed in plastic bags or they can be air dried and stored for documentation.

\section{Results}

SSCP analysis of PCR amplified exon 13 DNA fragments from 68 patients showed three characteristic banding patterns (fig 1). Pattern A was observed predominantly (for example, D21) with a frequency of about $81 \%$. The less abundant pattern B (for example, D58) and pattern $\mathrm{C}$ (for example, D108) had frequencies of $11.76 \%$ and $7.35 \%$, respectively (table 1 ). In addition to the characteristic band pattern types, a very small mobility shift of only the upper single DNA strand was detectable in the sample of patient D64 (fig 1). Sequence analyses comparing band pattern types $\mathrm{A}, \mathrm{B}$, and $\mathrm{C}$ identified point mutations in the $5^{\prime}$ adjacent intron sequence of exon 13 (table 2) at positions nt-72 and nt- 67 relative to the first coding nucleotide of the exon, obviously representing sequence polymorphisms.

Direct sequencing of two independently amplified PCR products from patient D64 and a normal control showed a single base change in the first position of the third coding triplet of exon 13. The sequence change $\mathrm{C}$ to $\mathrm{T}$ (fig 2) creates a stop codon (TAA). Therefore a truncated non-functional dystrophin molecule has to be expected, representing only $14 \%$ of the full sized protein. This observation correlates well with the severe clinical picture of the patient. The first symptoms were detectable when the patient started to walk and he became wheelchair bound at the age of 9 years.

\section{Discussion}

We amplify exon 13 and parts of the flanking intron of the dystrophin gene routinely as part of the screening for major rearrangements in $\mathrm{DMD} / \mathrm{BMD}$ patients. So far we have screened 72 males and detected four deletions that include exon 13. The PCR products of the remaining 68 patients without deletions were analysed for sequence alterations by a nonisotopic PCR-SSCP approach consisting of non-denaturing polyacrylamide gel electro-

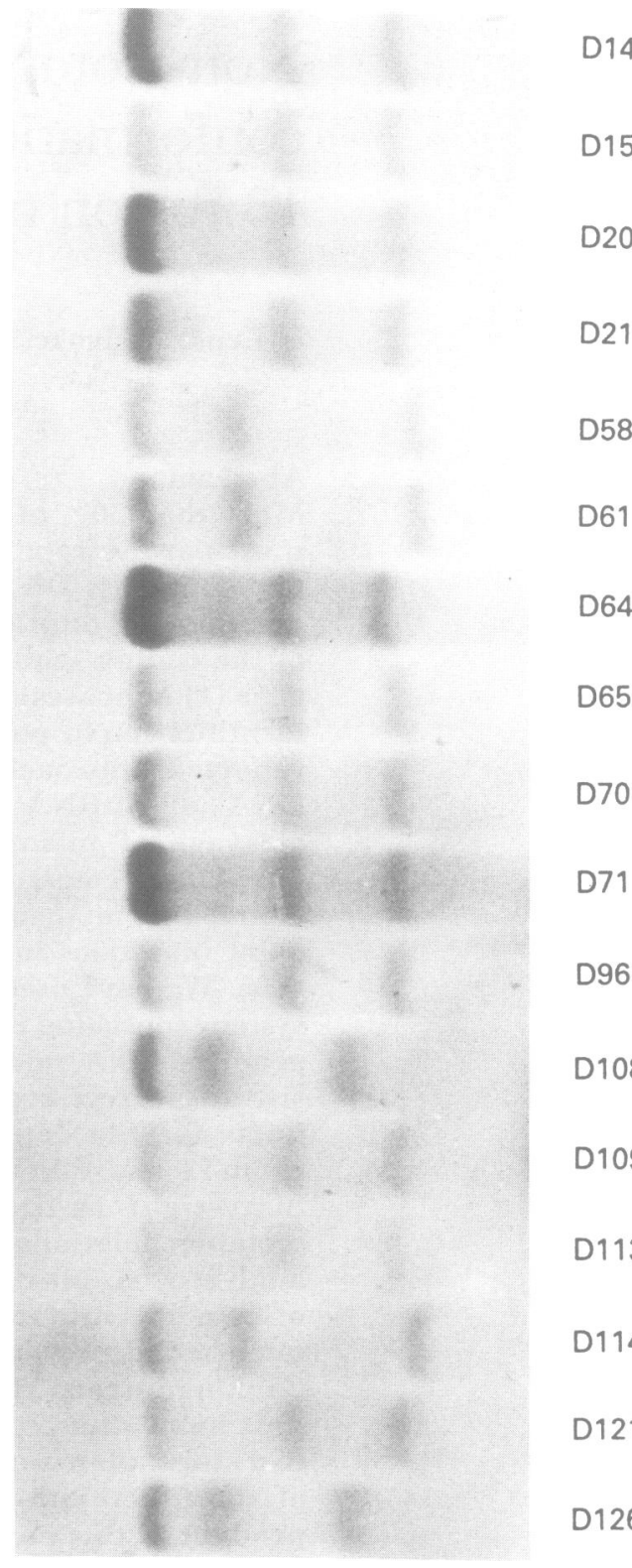

Figure 1 Exon 13 PCR-SSCP analysis of 17 $D M D / B M D$ patients. Electrophoresis was performed at $20^{\circ} \mathrm{C}$ in a $5 \%$ PAA gel containing $10 \%$ glycerol for five to seven hours at $500 \mathrm{~V}$. After silver staining (Diagen) we distinguished three different band patterns: the predominant type $A$ (for example, sample D21) and two less abundant patterns, type $B$ (for example, sample D58) and type $C$ (for example, sample D108). The SSCP sample of patient D64, marked with an asterisk, exhibits a very small mobility shift in only the upper single strand whereas the other comigrates with the band of the second strand of the predominant band pattern type $A$.

Table 1 Polymorphisms in exon 13 flanking sequences identified by non-isotopic SSCP analysis.

\begin{tabular}{lcc}
\hline $\begin{array}{l}\text { Location (relative to the } \\
\text { first nucleotide of exon 13) }\end{array}$ & Sequence change & Frequency \\
\hline nt-67 & A to T & $5 / 68=7.35 \%$ \\
nt-72 & T to C & $8 / 68=11.76 \%$ \\
\hline
\end{tabular}


Table 2 Polymorphisms and the deficiency mutation (1587 C to T) in exon 13 and in the $5^{\prime}$ flanking intron sequence. The PCR primer sequence $(13 F)$ and the mutant stop codon of patient D64 are underlined. Intron sequences are given in lower case letters and exon sequences in capitals. Nucleotide exchanges are indicated below the corresponding position in the reference sequence and the positions relative to the first coding nucleotide of exon 13 are marked above the sequence tracts.

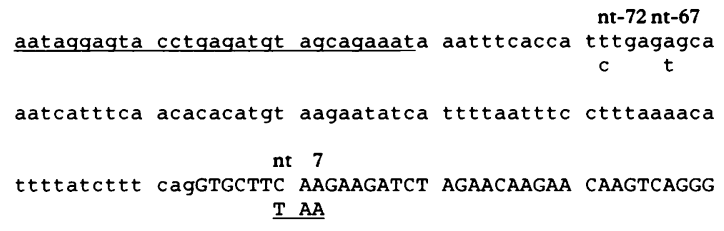

phoresis and a sensitive silver staining procedure.

In our study we have detected one point mutation which generates a termination codon causing a loss of more than $85 \%$ of the dystrophin coding sequence. In addition, two sequence polymorphisms with a frequency of $11 \cdot 76 \%$ and $7 \cdot 35 \%$, respectively, were identified in the $5^{\prime}$ flanking intron. In a recent study Nigro et $a l^{23}$ reported a polymorphism in the exon 13 region, but since sequence data were not available in this paper we were unable to compare our two polymorphisms with the reported one.

Different techniques are used in RNA or DNA approaches for the detection of the 30 to $40 \%$ of DMD/BMD causing mutations representing no gross gene rearrangements: chemical cleavage of amplified products of reverse transcribed dystrophin $\mathrm{mRNA}^{7}$ or PCR amplified genomic $\mathrm{DNA}^{8}$ and radioactive multiplex PCR-SSCP. ${ }^{23}$

Despite the technical difficulties the RNA approach offers the advantage that several exons can be analysed simultaneously, but in cases of exon skipping the analysis has to be extended to the genomic level in order to identify the presumed splice site mutation which frequently occurs in the flanking intron sequence. In addition, because of the extreme sensitivity of RT-PCR, there is always the risk of amplifying rare, aberrantly spliced products from the ectopic dystrophin transcripts, ${ }^{24}$ complicating the identification of any corresponding mutation.

For the dystrophin gene, the genomic SSCP approach requires extensive efforts for PCR amplification and gel analysis. However, when all sequence data are available for one subject all 79 exons, including splice site sequences in flanking introns, could be amplified in a single microtitre plate. The capacity of our electrophoresis devices would allow 79 exons plus available reference samples to be analysed within two or three days. When the technical and experimental prerequisites are well established for the genomic approach by PCRSSCP it should be possible to perform a complete screening of one patient within a week, which is comparable to the RNA approach using chemical cleavage.

An increasing number of studies dealing with the search for sequence variants or point mutations in human genes have used PCRSSCP approaches, both radioactive and nonisotopic. ${ }^{2526}$ Although this method is limited to relatively small DNA fragments, and although in rare cases some mutations may not be detectable under certain conditions of electrophoresis, ${ }^{27-29}$ PCR-SSCP has become more important and widely applied. Therefore we used PCR-SSCP and found it fast, easy to handle, and reproducible. We preferred the non-isotopic method because of the very sensitive visibility of the smallest migration shifts in relatively short gel runs (three to four hours) which might not be detectable in radioactive approaches in cases of strong signals. Owing to possible interfering effects of single stranded DNA fragments when two or more fragments of relatively small size differences are analysed in a multiplex gel run (especially under different conditions of electrophoresis), we only analysed single amplified exons. This avoids possible masking of very slight migration shifts.

Chemical cleavage for detecting single base exchanges seems to be a relatively effective approach. While in an RNA approach Roberts et $a l$ detected mutations in all seven patients analysed, Kilimann et al, ${ }^{8}$ performing a study with amplified genomic DNA, did not observe the exon 13 flanking intron polymorphisms that we found in our study. However, the chemical cleavage method is technically demanding and time consuming, and it involves the use of hazardous chemicals and radioactive labelling. In addition, the labelled probes have a limited applicability because of the half life period of the label, requiring preparation of probes for nearly every new $\mathrm{DMD} / \mathrm{BMD}$ case in routine diagnosis. Though virtually all mutations can be detected by the well established chemical cleavage method, these circumstances might prevent its wider application in clinical and forensic tests.

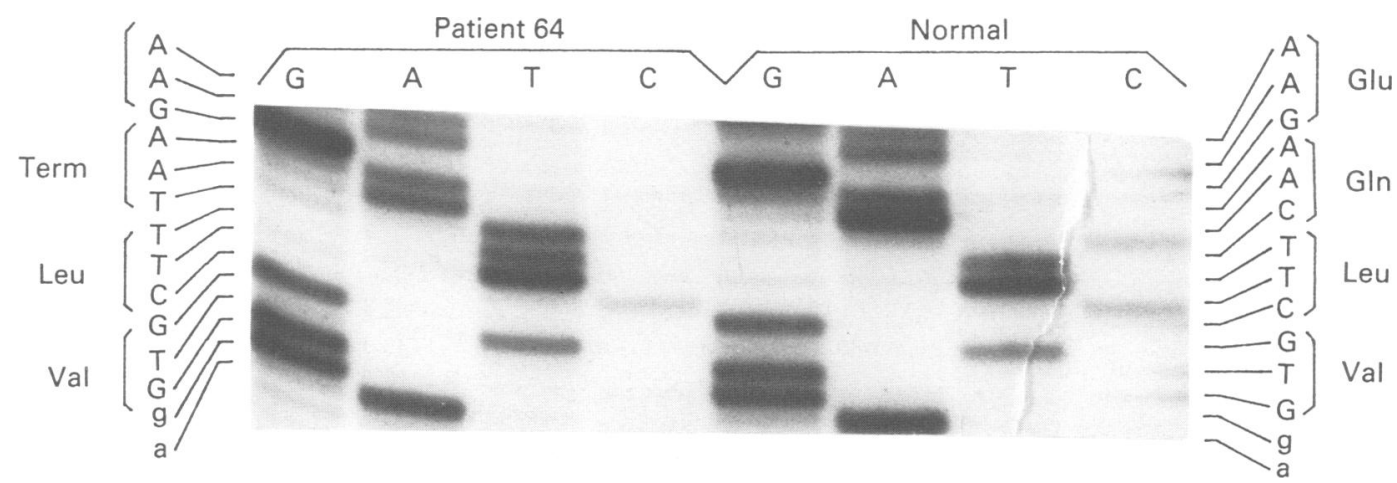

Figure 2 Direct sequencing of the intron-exon boundary of patient D64 compared to a wide type sequence. The mutation is shown as a $C$ to $T$ change in the first position of codon 490 resulting in a termination signal (TAA). 
Despite the fact that both approaches discussed have advantages and disadvantages which may result in a general preference of one method considering specific technical and experimental conditions, both chemical cleavage and PCR-SSCP using either RNA or genomic DNA represent equally suitable methods for systematically searching for sequencing variations in the human dystrophin gene.

This work was supported by the Deutsche Forschungsgemeinschaft. We are particularly grateful to A W J Spiegler for the clinical data.

1 Forrest SM, Cross GS, Speer A, Gardner-Medwin D, Burn J, Davies KE. Preferential deletion of exons in Duchenne and Becker muscular dystrophy. Nature 1987;329:638-40.

2 Koenig M, Hoffman EP, Bertelson CJ, Monaco AP, Feener C, Kunkel LM. Complete cloning of the Duchenne muscular dystrophy (DMD) cDNA and preliminary genomic organization of the DMD gene in normal and affected individuals. Cell 1987;50:509-17.

3 Prior TW. Genetic analysis of the Duchenne muscular dystrophy gene. Arch Pathol Lab Med 1991;115:984-90.

4 Koenig M, Monaco AP, Kunkel LM. The complete sequence of dystrophin predicts a rod-shaped cytoskeletal quence of dystrophin predicts

5 Roberts RG, Coffey JC, Bobrow M, Bentley DR. Determination of the exon structure of the distal portion of the
dystrophin gene by vectorette PCR. Genomics dystrophin gen

6 Bulman DE, Gangopadyhay SB, Bebchuk KG, Worton RG, Ray PN. Point mutation in the human dystrophin gene: identification through Western blot analysis. Genomics 1991;10:457-60

7 Roberts RG, Bobrow M, Bentley DR. Point mutations in the human dystrophin gene. Proc Natl Acad Sci USA 1992;89:2331-5.

8 Kilimann MW, Pizzuti A, Grompe M, Caskey CT. Point mutations and polymorphisms in the human dystrophin gene identified in genomic DNA sequences amplified by multiplex PCR. Hum Genet 1992;89:253-8.

9 Cotton RGH, Rodrigues NR, Campbell RD. Reactivity of cytosine and thymidine in single-base-pair mismatches cytosine and thymidine in single-base-pair mismatches with hydroxylamine and osmium tetroxide and its appli-
cation to the study of mutations. Proc Natl Acad Sci USA cation to the study

10 Grompe M, Muzny DM, Caskey CT. Scanning detection of mutations in human ornithine transcarbamoylase by chemical mismatch cleavage. Proc Natl Acad Sci USA 1989;86:5888-92.

11 Orita M, Iwahana H, Kanazawa K, Sekiya T. Detection of polymorphisms of human DNA by gel electrophoresis as single strand polymorphisms. Proc Natl Acad Sci USA 1989;86:2766-70

12 Orita M, Suzuki Y, Sekiya T, Hayashi K. Rapid and sensitive detection of point mutations and DNA polymorphisms using the polymerase chain reaction. Genomics phisms using

13 Spinardi L, Mazars R, Theillet C. Protocols for an improved detection of point mutations by SSCP. Nucleic Acids Res 1991;18:973-8.

14 Plieth J, Rininsland F, Schlösser M, Cooper DN, Reiss J Single strand conformation polymorphism (SSCP) analy sis of exon 11 of the CFTR gene reliably detects more than one third of non- $\Delta$ F508 mutations in German cystic fibrosis patients. Hum Genet 1992;88:283-7.

15 Berger W, van de Pol D, Warburg M, et al. Mutations in the candidate gene for Norrie disease. Hum Mol Genet 1992;1:461-5.

16 Batch JA, Williams DM, Davies HR, et al. Androgen receptor gene mutations identified by SSCP in fourteen subjects with androgen insensitivity syndrome. Hum Mol subjects with androgen
Genet 1992;1:497-503.

17 Ainsworth PJ, Surh LC, Coulter-Mackie MB. Diagnostic single strand conformational polymorphism (SSCP): simplified non-radioisotopic method as applied to TaySachs B1 variant. Nucleic Acids Res 1991;19:405-6.

18 Dockhorn-Dworniczak B, Dworniczak B, Brömmelkamp L, Bülles J, Horst J, Böcker WW. Non-isotopic detection of single strand conformation polymorphism (PCRSSCP): a rapid and sensitive technique in diagnosis of pSCP): a rapid and sensitive technique in diagn

19 Mohabeer AJ, Hiti AL, Martin WJ. Non-radioactive single strand conformation polymorphism (SSCP) using the Pharmacia "Phastsystem". Nucleic Acids Res 1991, 19:3154.

20 Davies KE, Speer A, Hermann F, et al. Human X chromosome markers and Duchenne muscular dystrophy. Nucleic Acids Res 1985;13:3419-4326.

21 Saiki RK, Gelfand DH, Stoffel S, et al. Primer-directed enzymatic amplification of DNA with a thermostable DNA polymerase. Science 1988;239:487-91.

22 Beggs AH, Koenig M, Boyce FM, Kunkel LM. Detection of $98 \%$ of $\mathrm{DMD} / \mathrm{BMD}$ gene deletions by polymerase chain reaction. Hum Genet 1990;86:45-8.

23 Nigro V, Politano L, Nigro G, Romano SC, Molinari AM Puca GA. Detection of a nonsense mutation in the dystrophin gene by multiplex PCR. Hum Mol Gene 1992;1:517-20.

24 Lenk U, Demuth S, Kräft U, Hanke R, Speer A. Alternative splicing of dystrophin mRNA complicates carrier determination: report of a DMD family. $₹$ Med Genet 1993;30:206-9.

25 Murakami Y, Suzuki Y, Kishimoto Y, Hirohashi S, Hayashi K, Sekiya T. Detection of DNA aberrations in human cancers by single strand conformation polymorphism analysis of polymerase chain reaction products. Tohoku 7 Exp Med 1993;168:247-55.

26 Tsai MY, Holzknecht R, Tuchman M. Single-strand conformational polymorphism and direct sequencing applied to carrier testing in families with ornithine transcarbamoylase deficiency. Hum Genet 1993;91:321-5.

27 Hayashi K. PCR-SSCP: a simple and sensitive method for detection of mutations in genomic DNA. Amplification: PCR methods and applications. New York: Cold Spring PCR methods and applications. New

28 Hayashi K. PCR-SSCP. a method for detection of mutations. Genetic Analysis: Techniques and Applications 1992;9:73-9.

29 Condie A, Eeles R, Borresen AL, Coles C, Cooper C, Prosser J. Detection of point mutations in the p53 gene comparison of single-strand conformation polymorphism, constant denaturant gel electrophoresis, and hydroxylamine and osmium tetroxide techniques. Hum Mutat 1993;2:58-66. 